Supplement of Biogeosciences, 17, 1231-1245, 2020 https://doi.org/10.5194/bg-17-1231-2020-supplement (C) Author(s) 2020. This work is distributed under the Creative Commons Attribution 4.0 License.

(c) (1)

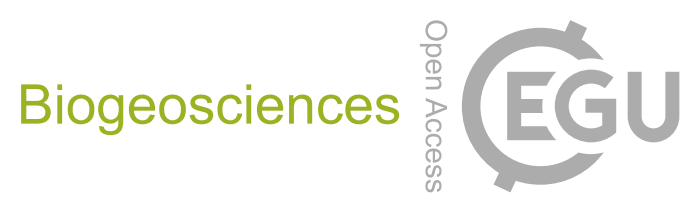

Supplement of

\title{
Deep-sea sponge grounds as nutrient sinks: denitrification is common in boreo-Arctic sponges
}

\section{Christine Rooks et al.}

Correspondence to: Friederike Hoffmann (friederike.hoffmann@uib.no)

The copyright of individual parts of the supplement might differ from the CC BY 4.0 License. 


\section{Schulz Bank}

\section{Norwegian Sea}
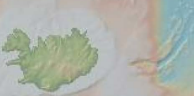

$ร$

Korsfjord
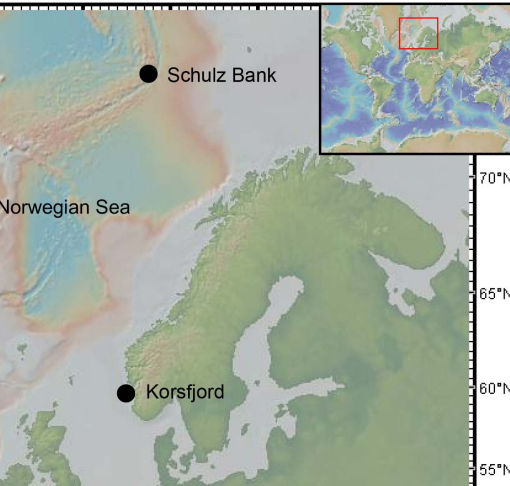
Figure supplementary material:

Map showing the two sampling sites Schulz Bank and Korsfjord. Map source (background): GeoMap App v. 3.6.6 